\title{
Recent Technologies Using Waste Materials/Byproducts For Sustainable Development
}

\author{
Satander kumar ${ }^{1}$, Ankit Sharma $^{2}$, Mohit Goel $^{3}$ \\ ${ }^{1}$ (Ex-scientist,Central Road Research Institute, New Delhi-110020,INDIA) \\ ${ }_{2}^{2}$ (Department Of Civil Engineering,Deenbandhu Chhotu Ram University Of Science And Technology,Murthal \\ (Sonepat)-131039, Haryana,INDIA) \\ ${ }^{3}$ (Department Of Civil Engineering,Deenbandhu Chhotu Ram University Of Science And Technology,Murthal
}

(Sonepat)-131039, Haryana,INDIA)

\begin{abstract}
Sustainability and long term performance of concrete structures are the two important criteria with respect to the prevailing environmental conditions. Sustainability can not be sacrificed to attain high strength. High ultimate strength is generally accompanied by a low W/C ratio. This is not, in itself, adequate to satisfy all sustainability related requirements. All types of concrete used in different applications must provide acceptable frost resistance, repeated heat resistance, sufficient fatigue life and adequate serviceability. Such concretes are made with the use of mineral admixture by partly replacing Portland cement or aggregate. Good quality fine particles of waste materials or byproducts particularly mineral admixtures and superplasticizer make the cement concrete sustainable with improved long term performance because of least permeability and very slow chemical reaction with harmful compounds present in the concrete. Granulated blast furnace slag, fly ash and silica fume are the major mineral admixtures which are byproducts of the steel, power and alloy industries which do not require much further processing (grinding or heating etc.) before their use in the concrete except in case of granulated blast furnace slag which need only grinding. Even, the energy consumed by these mineral admixtures and other byproducts of the Industry could be re-utilized also.

Minimum use of natural resources and recycling of unused materials are key elements in sustainable development. Unprecedented rise in our urban population, traffic population and a rapidly changing construction scenario have put tremendous pressure on available resources and carrying capacity of our ecosystem. The paper deals with the studies showing the ability of the concrete containing waste materials as compared to conventional concrete, to protect embedded steel from corrosion and concrete from other environmental effects for a very longer service period.
\end{abstract}

Keywords: Sustainable development, self compacting concrete, white topping

\section{Introduction}

The first cement plant in India came up in Porbander, Gujarat in 1914 and the first concrete road in India was constructed in Chennai in the same year. Indian cement industry, being the second largest in the world, has the annual production capacity of cement 115 million tones (apprx.).

The waste materials which may commonly be used in road construction are: fly ash, steel slag, broken bricks, debris from the concrete and other building structures, rice husk ash, lime sludge, marble slurry dust, silica fume (a by product of ferro silicon alloy industries), phospho-gypsum, kimberlite tailings from Panna mines, iron ore wastes, recycled bituminous and cement concrete materials etc. Some of the advantages of waste materials are:

Wide spread availability,

- Less haulage cost as compared to borrow soil or other conventional materials, as there is generally a ban on mining of sand / aggregate or use of top soil in some metro cities,

- Flyash/slag/silica fume mitigate alkali silica reaction,

- Low energy requirement and environment friendly,

A detailed research work on the use of phospho-gypsum in making concrete roads, has been done at the department of Civil Engineering and Applied Mechanics, Shri Govind Ram Sakseria Institute of Sciences and Technology, Indore (MP). Research work has also been done at Florida Institute of Phosphate Research Institute, Bartow, Florida in 1988 and at other Institutes in India and abroad. 10 percent phospho-gypsum in cement concrete gives, 5-10 per cent increase in compressive strength for M-20 grade concrete.

Nearly, 10 million tonnes of blast furnace slag becomes available from steel plants in India. About 5 million tonnes of blast furnace steel slag annually is being produced as granulated slag, which is mainly used in the manufacture of Portland blast furnace slag cement (IS 455-1989) either by inter-grinding or blending after grinding. 
The concept of milling to get milled materials is to use existing roads as quarry from which road stone aggregate can be reclaimed. The material removed from the highly distressed bituminous roads by milling machine (grinding) is called milled materials. Milled materials are stabilised with various additives like cement, emulsions, RBI grade 81 , etc. When the stone aggregates are replaced by milled materials partly or fully, the behavior of milled material in the base course is comparable to conventional base courses.

As per IRC:63-1976 "Tentative Guidelines for the Use of Low Grade Aggregate and Soil Aggregate Mixtures in Road Pavement Construction", the debris materials of the concrete structures/buildings, brick bats, mortar and concrete as sub base may be used after evaluating their properties especially grading and crushing strength alone or in combination with other binders /additives (5-10\%).

The country is generating around 110 million tonnes of fly ash per annum from its coal based thermal power plants. Silica fume is a byproduct of ferro-silicon alloy industries. Silica fume particles are ultra fine and siliceous in nature containing more than 85 percent reactive silicon dioxide which is about two times more than the silicon dioxide content present in the fly ash collected by electro-static precipitators.

Fly ash normally has lime reactivity of 50-60 kg/ sq. $\mathrm{cm}(5-6 \mathrm{M} \mathrm{Pa})$ or even more, where as the minimum specified value of lime reactivity is $45 \mathrm{~kg} / \mathrm{sq}$. cm as per IS: $3812-2003$. A good quality silica fume ( as mineral admixture) is now available in India from the private firms including firms dealing with superplasticizers. High performance concrete mixes can be designed very easily by using slag, fly ash and silica fume partly and adding superplasticizers into the fresh wet concrete up to maximum 2.0 percent (preferably less than 0.5 percent) by weight of cement to achieve desired workability. This slag has potential reactivity and need alkaline medium for activation. Globally, a mixture of all the three is also being used as a replacement of Portland cement for making high strength and high performance concrete. The reason being higher cement content than specified will reduce the life of the structure and pavement and with regard to objective of sustainability of the pavement will be far away from our reach once the structure or pavement is built.

\section{Properties Of Materials}

i) Cements: The cements when tested for various physical and chemical properties shall conform to Table 1 .

Table 1: Properties of Ordinary Portland Cements

\begin{tabular}{|c|c|c|c|}
\hline \multirow[b]{2}{*}{ SI No. } & \multirow[t]{2}{*}{ Characteristics } & \multicolumn{2}{|c|}{ Requirement as per } \\
\hline & & $\begin{array}{l}\text { IS:8112- } \\
1989 \\
\text { (43 Grade) }\end{array}$ & $\begin{array}{l}\text { IS 12269- } 1987 \\
\text { (53 Grade) }\end{array}$ \\
\hline 1 & Blain's Fineness, $\mathrm{m}^{2} / \mathrm{kg}$ & $\begin{array}{l}\text { Not less than } \\
225\end{array}$ & $\begin{array}{l}\text { Not less than } \\
225\end{array}$ \\
\hline 2 & $\begin{array}{l}\text { Setting Time, minutes: } \\
\text { Initial } \\
\text { Final }\end{array}$ & $\begin{array}{l}\text { Not less than } \\
30 \\
\text { Not more } \\
\text { than } 600\end{array}$ & $\begin{array}{l}\text { Not less than } \\
30 \\
\text { Not more than } \\
600\end{array}$ \\
\hline 3 & $\begin{array}{l}\text { Soundness : } \\
\text { Le-Chatelier Exp., mm } \\
\text { Autoclave Exp., \% }\end{array}$ & $\begin{array}{l}\text { Not more } \\
\text { than } 10 \\
\text { Not more } \\
\text { than } 0.8\end{array}$ & $\begin{array}{l}\text { Not more than } \\
10 \\
\text { Not more than } \\
0.8\end{array}$ \\
\hline 4 & $\begin{array}{l}\text { Compressive Strength, } \mathrm{N} / \mathrm{mm}^{2} \text {. } \\
3 \text { days } \\
7 \text { days } \\
28 \text { days } \\
\end{array}$ & $\begin{array}{c}\text { Not less than } \\
23 \\
33 \\
43 \\
\end{array}$ & $\begin{array}{c}\text { Not less than } \\
27 \\
37 \\
53 \\
\end{array}$ \\
\hline 5 & 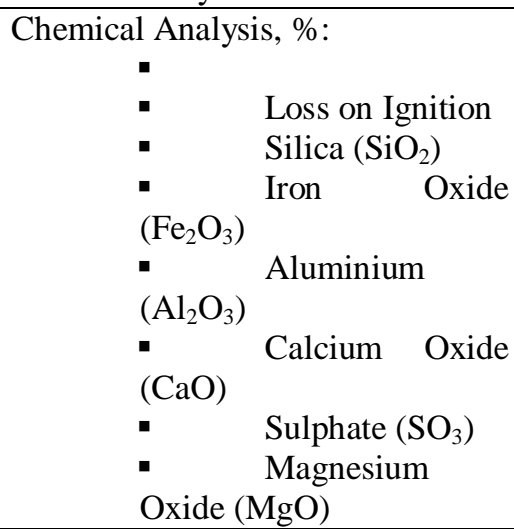 & $\begin{array}{c}\text { Not more } \\
\text { than } \\
5.0 \\
- \\
- \\
- \\
- \\
2.5 \\
6.0\end{array}$ & $\begin{array}{c}\text { Not more than } \\
4.0 \\
- \\
- \\
- \\
- \\
2.5 \\
6.0\end{array}$ \\
\hline
\end{tabular}


ii) Coarse and Fine Aggregates: Various tests on aggregates shall conform to Table 2.

Table 2: Properties of Coarse and Fine Aggregates

\begin{tabular}{|l|l|l|}
\hline SI No. & $\begin{array}{l}\text { Coarse } \\
\text { Aggregates }\end{array}$ & $\begin{array}{l}\text { Requirement as per IS: 383- } \\
\mathbf{1 9 7 0 / N o r m a l ~ r a n g e ~}\end{array}$ \\
\hline 1 & $\begin{array}{l}\text { Specific } \\
\text { Gravity }\end{array}$ & $2.5-2.8$ \\
\hline 2 & $\begin{array}{l}\text { Water } \\
\text { absorption, } \%\end{array}$ & Max 2.0 \\
\hline 3 & $\begin{array}{l}\text { Impact Value, } \\
\%\end{array}$ & Not more than 30 \\
\hline 4 & $\begin{array}{l}\text { Crushing } \\
\text { Value, } \%\end{array}$ & Not more than 30 \\
\hline 5 & $\begin{array}{l}\text { Flakiness } \\
\text { Index, \% }\end{array}$ & $30-40$ \\
\hline \multicolumn{3}{|c|}{ Fine Aggregate } \\
\hline 1 & $\begin{array}{l}\text { Fineness } \\
\text { Modulus }\end{array}$ & $2.5-3.0$ \\
\hline 2 & $\begin{array}{l}\text { Silt Content, } \\
\%\end{array}$ & Not more than $5 \%$ \\
\hline 3 & $\begin{array}{l}\text { Specific } \\
\text { Gravity }\end{array}$ & $2.5-2.8$ \\
\hline 4 & $\begin{array}{l}\text { Water } \\
\text { Absorption, } \\
\%\end{array}$ & $1.0-2.0$ \\
\hline
\end{tabular}

iii) Superplasticiser

Various tests carried out as per IS: 9103-1999 shall conform to Table 3.

Table 3: Tests on Superplasticisers as per IS: 9103-1999

\begin{tabular}{|c|c|c|}
\hline $\begin{array}{l}\text { Sl. } \\
\text { NO }\end{array}$ & Tests & $\begin{array}{l}\text { Limits As per IS:9103- } \\
1999 \text { Normal Type }\end{array}$ \\
\hline 1 & Water Content, \% of control sample & Max 80 \\
\hline 2 & $\begin{array}{l}\text { Time of setting, allowable deviation from control sample } \\
\text { Minutes } \\
\text { Initial } \\
\text { Final }\end{array}$ & $\begin{array}{l}\text { Min }+1.5 \text { hours } \\
\text { Max } \pm 1.5 \text { hours }\end{array}$ \\
\hline 3 & $\begin{array}{l}\text { Compressive strength, \% of control sample } \\
1 \text { Day } \\
3 \text { Day } \\
7 \text { Day } \\
28 \text { Day }\end{array}$ & $\begin{array}{l}\text { Min. } 125 \\
\text { Min } 125 \\
\text { Min } 115\end{array}$ \\
\hline 4 & $\begin{array}{l}\text { Flexural strength, \% of control sample } \\
3 \text { Day } \\
7 \text { Day } \\
28 \text { Day }\end{array}$ & $\begin{array}{l}\text { Min. } 110 \\
\text { Min. } 100 \\
\text { Min. } 100\end{array}$ \\
\hline 5 & Bleeding, \% increase over control sample & Max 5 \\
\hline 6 & Air content, $\%$ over control & Max. 1.5 \\
\hline 7 & Length change, $\%$ increase over control at 28 day & Max. 0.01 \\
\hline 8 & Loss of workability $(\mathrm{mm})$, deviation from control & $\begin{array}{l}\text { At } 45 \text { min. the slump } \\
\text { shall be not less than that } \\
\text { of control mix concrete } \\
\text { at } 15 \text { min. }\end{array}$ \\
\hline 9 & Slump/Flow (mm) & $\begin{array}{l}\text { Not more than } 15 \mathrm{~mm} \\
\text { below that of the control } \\
\text { mix concrete }\end{array}$ \\
\hline
\end{tabular}


iv) Fly Ash

The properties are given in Table 4.

Table 4: Properties of Fly Ash

\begin{tabular}{|c|c|c|}
\hline SL NO & Type of Testing & Requirement (\%) as per IS : 3812-2003 \\
\hline 1 & Loss on ignition & Max 5 \\
\hline 2 & $\mathrm{SiO}_{2}$ & - \\
\hline 3 & $\mathrm{Fe}_{2} \mathrm{O}_{3}$ & - \\
\hline 4 & $\mathrm{Al}_{2} \mathrm{O}_{3}$ & - \\
\hline 5 & $\mathrm{CaO}$ & Max. 5 \\
\hline 6 & $\mathrm{MgO}$ & Max 2.75 \\
\hline 7 & $\mathrm{SO}_{3}$ & Min. 320 \\
\hline 8 & Fineness(m $2 / \mathrm{kg})$ & Min. 4.5 \\
\hline 9 & Lime Reactivity $\left(\mathrm{N} / \mathrm{mm}^{2}\right)$ & Not less than $80 \%$ of the strength of \\
& corresponding plain cement mortar \\
\hline 10 & $\begin{array}{c}\text { Comentrol } \\
\text { Fly ash mix }\end{array}$ & Max. 0.15 \\
\hline 11 & Drying Shrinkage (\%) & Max 0.8 \\
\hline 12 & Soundness (\%) &
\end{tabular}

\section{v) Silica Fume}

Micro silica is available in the following four forms:

i ) Undensified: Its density is typically 200 to $350 \mathrm{~kg} / \mathrm{m}^{3}$. It is collected from the filters as a very light powder, which is used in making mortar and grout.

ii) Densified: It has a density of 500 to $700 \mathrm{~kg} / \mathrm{m}^{3}$. It is basically processed to increase the bulk density by loosely agglomerating the fine particles. This form is not as 'dusty' as undensified micro-silica and has a fine granular appearance and is being used in ready-mix concrete and pre-cast products.

iii) Palletised: Its density is around $1,000 \mathrm{~kg} / \mathrm{m}^{3}$. This form is treated with a small amount of cement and water to give solid agglomerate. It is normally used only for inter-grinding with cement and cannot disperse beyond the actual grinding.

iv) Slurry: It is an aqueous suspension of undensified micro-silica in water, usually in the ratio of 1:1 (by weight). The material has a specific gravity of around 1.4 and as a liquid, is easier to handle than the powders. Slurry freshly made shall be frequently agitated to avoid setting out micro silica fume particles. The slurry shall be used only on a day-to-day and batch-to-batch basis. The slurry may contain other agents to maintain the suspension and the effect of these on the finished concrete would have to be assessed. Various tests carried out on silica fume shall conform to ASTM: C 1240-2001 or IS Specification.

Properties of silica fume are given in Table 5.

Table 5: Test Results of Silica Fume

- (a) Chemical Properties

\begin{tabular}{|c|c|c|}
\hline $\begin{array}{r}\text { SI } \\
\text { No } \\
\end{array}$ & Type of Testing & Test Value as per IS: $15388-2003$ \\
\hline 1 & Loss on ignition (\%) & $6 \max$ \\
\hline 2 & $\mathrm{SiO}_{2}(\%)$ & $85 \max$ \\
\hline 3 & Total Alkalies (\%) $\left(\mathrm{Na}_{2} \mathrm{O}\right.$ Eqvt) & $1.5 \max$ \\
\hline 4 & Moisture content & $3 \max$ \\
\hline \multicolumn{3}{|c|}{ (b) Physical Properties } \\
\hline 1 & Residue on $45 \mu$ sieve (\%) & $10 \max$ \\
\hline 2 & Density $\left(\mathrm{kg} / \mathrm{m}^{3}\right)$ & - \\
\hline 3 & Bulk Density $\left(\mathrm{kg} / \mathrm{m}^{3}\right)$ & - \\
\hline 4 & Drying Shrinkage (\%) & $\begin{array}{l} \\
\circ\end{array}$ \\
\hline 5 & Cement Reactivity $\left(\mathrm{N} / \mathrm{mm}^{2}\right)$ & $85 \%$ of Control min \\
\hline
\end{tabular}


Note- SF -Silica Fume, OPC- Ordinary Portland Cement, G- Grade, max- maximum

\section{Durability}

To improve the durability of the concrete containing very fine particles, following admixtures are generally

i) Accelerators

used as per the requirement:

ii) Retarders

iii) Water reducing agents which are termed plasticisers and superlasticisers viz.:

Sulphonated melamine-formaldehyde condensates (SMF)

Sulphonated nepthalene-formaldehyde condensates (SNF).

Modified lignosulphonates (MLS),

iv) Air-entraining agents

Sulphonic acid esters, carbohydrate esters etc.

Durability of concrete may be evaluated by the following tests:

- Chloride Ion Permeability Test (ASTM-C1202)

- Modulus of Elasticity

- Abrasion Resistance as per IS: 9284-1979.

- Bond Strength

- Cover to concrete

- Weathering durability tests

The durability of concrete by Chloride permeability test consists of monitoring the amount of electrical current passed through $51 \mathrm{~mm}$ thick slices of $102 \mathrm{~mm}$ nominal diameter cores or cylinders during a 6 hour period. A potential difference of $60 \mathrm{~V} \mathrm{DC}$ is maintained across the ends of the specimen, one of which is immersed in a sodium chloride solution and the other in a sodium hydroxide solution. The total charge passed, in coulombs, has been found to be related to the resistance of the specimen to chloride ion penetration. The results are used to assess qualitatively the chloride ion penetrability of concrete as indicated Table 6:

Table 6: Chloride Ion Permeability

\begin{tabular}{|l|c|c|}
\hline $\begin{array}{l}\text { Sl. } \\
\text { No. }\end{array}$ & Charge Passed (Coulombs) & Chloride Ion Permeability \\
\hline 1. & $>4000$ & High \\
\hline 2. & $2000-4000$ & Moderate \\
\hline 3. & $1000-2000$ & Low \\
\hline 4. & $100-1000$ & Very Low \\
\hline 5. & $<100$ & Negligible \\
\hline
\end{tabular}

The specimens may also be cast for weathering cycles to undergo (i) heating for 8 hours at $60^{\circ} \mathrm{C}$ and cooling them at $27^{\circ} \mathrm{C}$, (ii) keeping in $5 \%$ sodium sulphate solution at room temperature and heating them at $60^{\circ} \mathrm{C}$. , (iii) keeping the specimens at $-15^{\circ} \mathrm{C}$ and cooling them in air at room temperature. Visual observations may be made on the damages and deterioration caused.

Concrete Cover - Plain and Reinforced Concrete: As per clause 304.3 of IRC: 21-2000 regarding the cover of concrete to steel bar in case of plain and reinforced concrete bridges, the minimum clear cover to any reinforcement bar, closest to the concrete surface, shall be $40 \mathrm{~mm}$. Increased minimum cover thickness of 50 $\mathrm{mm}$ shall be provided when concrete members are exposed to severe conditions as mentioned in clause 4.0 on concrete except that for the condition of alternate wetting and drying and in case of foundations where the minimum clear cover shall be $75 \mathrm{~mm}$.

\section{New Technologies}

i) Self Compacted Concrete (SCC) has its own limitation- it can not, on its own, flow into nooks and corner of the form work. Through compaction, often using vibration is essential for achieving strength and durability of concrete. It has its own limitation depending on the types of structures, its dimensions, and types of reinforcement, location of structures etc. Self compacting concrete (SCC) may provide remedies to these problems. Developed by Prof. Okamura and his team in Japan in 1986, SCC has evolved as new innovative technology, capable of achieving status of being an out-standing advancement in the sphere of concrete technology. There are now many countries who are also working on SCC viz Sweden, Thailand, UK, India etc. 
No vibration is necessary for SCC which can flow around obstructions, encapsulate the reinforcement and fill up the space completely under self weight. The salient advantages are:

- Ensure through compaction employing unskilled labour

- Minimize repair of finished surface

- Ensure good finished surface

- Reduced manpower for casting and finishing

- Increase in speed of construction

- Improvement in the performance

Development of Self Compacted Concrete (SCC) is now being improved and is being used in the concrete industry. As a safe guard against separation of water, use of a viscosity modifying agent is usually essential to minimize shrinkage due to high powder content in SCC. There are typical mixes of SCC similar to conventional concrete where risk of cracking due to shrinkage and thermal stresses could be reduced. Addition of fly ash and other siliceous materials such as silica fume and granulated slag make 'Sustainable SCC'.

There are many organization/academic institutions/cement companies in India who are working in the laboratory and field for the advancement and use of SCC in structures. There is a need to formulate IRC/BIS specifications/ guidelines for the use of SCC in respective structures based on the experience/data gained in India. However, there are guidelines published by Hampshire, UK (EFNARC-2002)/contract documents on use of SCC in Nuclear Structures.

ii) High volume fly ash ( 35 to 90 per cent) concrete is the other area on which work has been carried for making roller compacted concrete pavement in China in 1998, USA, UK etc. There is early strength decrease, but strength will get sharp development later and high-grade cement benefit the early strength

iii) Soil stabilization is extensively used in European and African Countries to optimize and conserve natural resources. The preliminary estimate revealed that we require 175 million cubic meter of aggregate per annum. Such exploitation of natural resources would create serious environment issue. There is therefore need to develop and popularize alternate methods of road construction and thereby make the optimum use of natural material. This is also necessary to reduce diesel consumption required for transporting and processing these materials. There is a need to improve the engineering properties of traditional construction material to reduce the material consumption.. $10 \mathrm{~mm}$ stabilized soil is equivalent to $15 \mathrm{~mm}$ of unbounded granular layer which mean drastically reduction in aggregate consumption. Lime is used to stabilize clayey soil and cement is used for stabilization of sand soils. Now I the market, stabilizers are available such as RBI-Grade 81 which can be used both for sandy and clayey soil with long term performance.

iv) Ultra Thin White Topping (UTWT- The fourth major technology is Ultra Thin White Topping (UTWT) i.e laying of concrete over bituminous pavement with closer joint spacing, the details of which are given $n$ IRC:SP 76. UTWT involves the use of High Performance concrete (HPC) as per IRC:SP 70 and Ultra High performance Concrete i.e HPC containg fibres and special types of aggregates.

UTWT has been used in India, USA and U.K. as thin rigid overlay over flexible pavements. In case of ultra thin white topping (UTWT), existing bituminous layer is milled before laying UTW over bituminous layer. The minimum thickness of bituminous layer after milling shall be $75 \mathrm{~mm}$ for UTWT and also existing bituminous layer shall be free from major defects and cracking so that reflection cracks or sympathetic cracks are as minimum as possible. These cracks, if left out after milling, shall be repaired with either bituminous or cement concrete layer or any other suitable polymers to avoid reflection cracking. The basic purpose of UTWT is to improve the riding quality along with the load carrying capacity.

Salient features of UTW:

i) The roadway is milled to a uniform depth throughout the surface layer of asphalt,

ii) Edges of the milled area serve as forms and significantly reduce the cost of formwork,

iii) Polypropylene/polyester fibres are optional to add to enhance the toughness of UTWT

iv) Maximum $\mathrm{W} / \mathrm{C}$ ratio 0.33 ,

v) Concrete strength (Compressive) $=276 \mathrm{~kg} / \mathrm{sq} \mathrm{cm}$ at 3 days,

vi) Concrete is placed by slipform/fixed form to the finished grade of the existing roadway as per the facilities available,

vii) Joints spacing is normally kept at $100-150 \mathrm{~cm}$,

viii) Provides additional durability which is achieved due to the additional use of mineral admixtures, and 
ix) Bond between concrete overlay and the underlying asphalt, enable UTWT to act as a composite section and require less thickness of UTWT,

v) White topping (WT) is a conventional concrete overlay of 20-30 $\mathrm{cm}$ thick with a leveling layer of bituminous $\backslash$ macadam or dry lean concrete over a crack arresting layer over the existing bituminous layer or in some cases, existing bituminous layer is removed before white topping is laid, or repaired with the suitable materials. Mineral admixtures in the WT also will improve the sustainability of the pavement.

vi) Roller Compacted Concrete, Soil stabilization and others- There are other technologies which includes the use of byproducts which are - roller compacted concrete pavement (RCCP) (IRC:SP-68) i.e concrete pavement made with the use of roller/ soil compactor on low slump concrete, concrete, soil stabilization of weak soils, paver block for footpath, shoulder and even for carriageway at the round-abouts or crossings, flowable fills (containg very low quantity of Portland cement) or cement treated bases. Byproducts in these technologies may be used as soil or aggregate, replacement.

If the pavements which are designed and constructed for very longer period than conventional life, these are normally called perpetual pavements. This may be possible with the use of mineral admixtures in the concrete, soil stabilization or other byproducts as discussed.

\section{General Discussion And Conclusions}

There are many mineral admixtures, which are generally industrial by-products and are recommended as replacement of cement or sand in the concrete to increase the performance and durability of concrete structures and to reduce the high cost. Some times, it is very difficult to design the concrete mixes up to the expected level of quality and service in coastal or other typical areas with out the use of mineral admixtures. Fly ash, slag and silica fumes are as health hazard as cement and other reactive siliceous particles. These shall also be used in a similar way with proper care and bags shall be opened when required, but used within a period of six months.

A concrete pavement particularly made with mineral admixtures/ byproducts maintains the initial roughness of $2000 \mathrm{~mm} / \mathrm{km}$ only if it is very carefully and meticulously designed and constructed. Such pavements requires stricter quality control of both materials, which constitute the concrete, and process of laying the same, which otherwise result in failure. During lying of pavement quality or dry lean concrete, adequate quantity of water shall be added. If it is less than the requirement, some of the cement may remain un-hydrated and if it is more, there may be more shrinkage. By the use of byproducts, rigid pavements have some advantages:

- Shrinkage of concrete is directly proportional to water content per cubic meter of concrete,

- If compaction of concrete layer is excessive, there would be sometime, more free water on the top surface, there by causing more shrinkage cracks,

- Concrete pavement may perform well in areas having high rainfall, prone to water-logged and flooding where swelling pressure due to expansive soils, is very high.

- More service life

- Annual maintenance is very less,

- Less quantity of aggregates is required, conserving natural resources.

Use of mineral admixtures will not only enable substantial savings in the consumption of cement and energy, but also has many advantages such as: improvement in workability, decreases in permeability, decreases potential alkali aggregate reactivity, increases resistance to sulphate reaction, better finishing etc besides saving in time.

In town, streets particularly in North East and Uttar Pradesh, pavement can be made with bricks laid flat or on-edge over 50-75 mm of rammed ballast, lean cement concrete, well consolidated. The soil should also be well rammed and brought to camber or proper levels.

\section{References}

[1] IS: 1077 - 1992 Common Burnt Clay Building Bricks - Specifications

[2] S: 3495 - 1992 Methods of Tests of Burnt Clay Building Bricks - Part -1

Determination of Compressive Strength

[3] IS: 3495 - $1992 \quad$ Methods of Tests of Burnt Clay Building Bricks - Part -2 Determination of Water Absorption

[4] IS: 3495 - 1992 Methods of Tests of Burnt Clay Building Bricks - Part -3 Determination of Efflorescence 
[5] IS: $2180-1988$

[6] IS: $2248-1992$

Building

[7] IS: $5454-1978$

[8] IS: $1905-1987$

[9] IS: $3316-1974$

[10] IS: $3620-1979$

[11] IS: $4139-1976$

[12] IS $3812: 2003$

[13] IS $269: 1989 \mathrm{Sp}$

[14] IS $650: 1966$

[15] IS $1344: 1981$

[16] IS $1727: 1967$

[17] IS $2580: 1982$

[18] IS $3535: 1986$

[19] IS $4032: 1985$

[20] IS $4845: 1968$

[21] IS $4905: 1968$

[22] IS 11652: 1986

[23] IS $11653: 1986$

[24] IS 12089: 1987

Portland slag cement

[25] IS $12154: 1987$

[26] IS $12174: 1987$

[27] IS $12423: 1988 \quad$ Method for colourimetric analysis of hydraulic cement
[28] Technical Report on RBI-Grade 81, Legend Surface Developers Pvt Ltd, Sanik
Specification for Heavy Duty Burnt Clay building Bricks

Glossary of Terms Relating to Structural Clay Products for

Methods for Sampling of Clay building Bricks

Code of Practice for Structural Use of Unreinforced Masonary

Specification for Structural Granite

Specification for Laterite Stone Block for Masonry

Specification for Sand Lime Bricks

Specification for Fly Ash for use as Pozzolana and Admixture

cations for 33 grade ordinary Portland cement

Standard sand for testing of cement (first revision)

Specification for calcined clay pozzolana (second revision)

Methods of tests for pozzolanic materials (first revision)

Jute sacking bags for packing cement (second revision)

Methods of sampling of hydraulic cements (first revision)

Methods of chemical analysis of hydraulic cement

Definitions and terminology relating to hydraulic cement

Methods of random sampling

High density polyethylene woven sacks for packing cement

Polypropylene (PP) woven sacks for packing of cement

Specification for granulated slag for the manufacture of

Light weight jute bags for packing of cement

Jute synthetic union bags for packing of cement

Method for colourimetric analysis of hydraulic cement 